\title{
Humeral fracture repair using a robust fixation in an adult Giant Anteater (Myrmecophaga tridactyla): case report
}

[Reparo de fratura umeral usando uma fixação robusta em um tamanduá-bandeira adulto (Myrmecophaga tridactyla): relato de caso]

B.W. Minto, T.V. Magalhães, D.V.F. Lucena, I.M. Soriano, G.H.F. Barranco, L.G.G.G. Dias, K. Werther

Faculdade de Ciências Agrárias e Veterinárias - Universidade Estadual Paulista - Jaboticabal, SP

\begin{abstract}
The treatment of fractures from the thoracic limb in giant anteaters is extremely challenging. Unfamiliar and peculiar anatomical characteristics, robust musculature and the imminent need for an early return to limb function highlight such challenges. The objective of this report was to describe the successful use of anatomical osteosynthesis with a robust locking compression plate in a humeral fracture of an adult giant anteater. The patient was rescued on the highway after being run over and presented for treatment at the Veterinary Teaching Hospital. Surgical stabilization was performed using a craniomedial approach to the humerus, using a customized broad $3.5 \mathrm{~mm}$ locking compression plate. The patient presented early limb support at 24 hours postoperatively. Radiographic monitoring was performed at 30, 60 and 90 days postoperatively, and bone healing was observed without any complications. It is concluded that the treatment of humerus fractures in giant anteaters requires robust fixation. The use of a reinforced locking compression plate system proved to be effective and adequate to the mechanical load that an adult individual of this species needs for early use of the thoracic limb and, at the same time, efficient in controlling interfragmentary movement, which allowed fracture consolidation.
\end{abstract}

Keywords: bone consolidation, orthopedics, osteosynthesis, wild animal

\section{RESUMO}

O tratamento das fraturas do membro torácico dos tamanduás-bandeira (Myrmecophaga tridactyla) é extremamente desafiador. Características anatômicas pouco familiares e peculiares, musculatura muito desenvolvida e necessidade iminente de retorno precoce à função do membro destacam tais desafios. Objetivou-se, neste relato, descrever a utilização com sucesso da osteossíntese anatômica com placa bloqueada robusta em fratura umeral de um tamanduá-bandeira. O paciente foi resgatado em rodovia após atropelamento e atendido no Hospital Veterinário Universitário. Após sedação e avaliação física completa, foi realizado exame radiográfico, o qual revelou fratura completa oblíqua curta em diáfise média de úmero esquerdo. A estabilização cirúrgica foi realizada por abordagem craniomedial ao úmero, utilizando-se placa bloqueada (LCP) do sistema 3,5mm customizada. O paciente apresentou apoio precoce do membro com 24 horas de pós-operatório. Realizou-se acompanhamento radiográfico aos 30, 60 e 90 dias, sendo observada união clínica sem quaisquer complicações. Conclui-se que o tratamento das fraturas do úmero em tamanduás-bandeira exige robustez na fixação. A utilização de sistema reforçado de placa bloqueada mostrou-se efetiva e adequada à carga mecânica de que um indivíduo adulto dessa espécie necessita para uso precoce do membro torácico e, ao mesmo tempo, eficiente no controle da movimentação interfragmentária, o qual permitiu consolidação da fratura.

Palavras-chave: consolidação óssea, ortopedia, osteossíntese, silvestres

Recebido em 14 de setembro de 2020

Aceito em 19 de março de 2021

E-mail: brunowminto@gmail.com 


\section{Minto et al.}

\section{INTRODUCTION}

The human occupation of natural territories associated with the scarcity of food for several wild species, have greatly increased motor vehicle accidents on highways, as well as the receiving of polytraumatized and fractured wild animals in veterinary clinics practice (Alves et al., 2020). The lack of knowledge about physiology, anatomy and physio pathologic mechanism of diseases have been making this approach highly challenging (Zimmerman et al., 2010). Despite of few publications involving traumatic conditions and giant anteaters, the decision-making regarding therapeutic approach has been mostly based on personal experiences or knowledge from other animals, especially dogs and cats (Ferrigno et al., 2003; Sesoko, 2012).

Thoracic limb fractures require rigid fixation and effective bone consolidation, since this species is totally dependent on the thoracic limb to survive (Alves et al., 2020). Its arms are adapted to open termite nest walls and its claws specialized for defense, locomotion and obtaining food. In addition, thoracic limb muscles weigh almost twice the pelvic limb ones, requiring great resistance from the orthopedics implants (Sesoko, 2012). The robustness of these animals implies the need to select rigid implants that promote strong enough fixation, once they will certainly be challenged against their body weight and muscle's strength (Zimmerman et al., 2010). Additionally, the fixation should promote rapid recovery of limb function, low rate of complications and allow the animal to manifest its natural behavior, without compromising its ability to survive (Ferrigno et al., 2003). The present study aims to report a humeral osteosynthesis in an adult giant anteater (Myrmecophaga tridactyla) with a customized reinforced locking plate system.

\section{CASE REPORT}

An estimated $20 \mathrm{~kg}$, adult, female giant anteater (Myrmecophaga tridactyla) was received at Veterinary Teaching Hospital, presenting with non-weight bearing left thoracic limb lameness after being run over on a highway. Aggressive behavior and soft tissue edema in the level of left humerus were firstly observed. Dissociative anesthesia was performed, with the association of $5 \mathrm{mg} / \mathrm{kg}$ tiletamine and $5 \mathrm{mg} / \mathrm{kg}$ zolazepam
(Virbac, São Paulo, SP, Brazil), intramuscularly (IM). Subsequently, physical examination, initial emergency treatment, laboratory and radiographic examinations were performed.

Mild dehydration, left thoracic limb skin abrasions and signs of inflammation at the fracture site were observed. At this point, $50 \mathrm{ml} / \mathrm{kg} /$ day of ringer lactate (subcutaneously [SC]), $3 \mathrm{mg} / \mathrm{kg}$ of tramadol hydrochloride (Teuto, Cravinhos, SP, Brazil), IM, $7.5 \mathrm{mg} / \mathrm{kg}$ enrofloxacin (Bayer, São Paulo, SP, Brazil), IM, and $0.2 \mathrm{mg} / \mathrm{kg}$ on the first day and $0.1 \mathrm{mg} / \mathrm{kg}$ on the following days of meloxicam (Ouro Fino, Cravinhos, SP, Brazil), IM, were administered. The blood count and serum biochemistry were considered normal (Miranda, 2012). Radiography of the chest, skull, abdomen and limbs were performed with a digital radiography device (Digital Radiography Equipment; Siemens RG150/100gl, Munich, Germany), revealing a mid-diaphyseal short complete oblique fracture of the left humerus (Figure 1A). Surgical treatment was chosen and performed one day after the initial care.

Preanesthetic medication consisted of $10 \mathrm{mg} / \mathrm{kg}$ of ketamine (Syntec, Santana de Parnaíba, SP, Brazil), IM, $0.5 \mathrm{mg} / \mathrm{kg}$ of midazolam (Hipolabor, Sabará,mg, Brazil), IM, and $0.1 \mathrm{mg} / \mathrm{kg}$ of morphine (morphine sulfate, Cristália, Itapira, SP, Brazil), IM. Cannulation of the facial vein and trichotomy of the affected limb were performed. The patient was pre-oxygenated by mask for five minutes. Oxygenation was performed by a mask coupled to the Baraka circuit, providing 100\% oxygen $(1 \mathrm{~L} / \mathrm{min})$ and isoflurane (Cristália, Itapira, SP, Brazil, dose-effect).

The animal was placed in the supine position, with the limb extended caudally, according to the description for approach to the humerus of Sesoko (2012). The surgical site was aseptically prepared with $2 \%$ chlorhexidine (Riohex 2\%, Rioquímica, São José do Rio Preto, SP, Brazil) followed by chlorhexidine alcoholic $0.5 \%$ (Riohex $0.5 \%$, Rioquímica, São José do Rio Preto, SP, Brazil). A craniomedial approach to the humerus was performed, taking the pectoral tuberosity as a reference, very pronounced in this species. The incision was made medially to this tuberosity and extended across the diaphysis. After incision of the muscular fascia, the biceps brachial muscle and its heads were observed, which were 
separated to expose the humeral diaphysis. The cephalic vein was carefully retracted, and the pectoral muscle was incised to access the most proximal diaphysis. After reducing the fragments with a pointed bone forceps, a $3.5 \mathrm{~mm}$ broad LCP plate with nine holes (Focus ${ }^{\circledR}$, Indaiatuba, SP, Brazil) was firstly cut and properly contoured to suit the size of the bone, and then fixed with seven $3.5 \mathrm{~mm}$ screws applied to the caudolateral surface of the humeral shaft. Interfragmentary compression was achieved manually through the pointed bone forceps.

The pectoral muscle fascia was closed using 2-0 polyglecaprone 25 (Caprofyl, Ethicon, São Paulo, SP, Brazil), in a simple continue suture pattern, as well as the subcutaneous tissue. The skin was sutured with 2-0 nylon (Mononylon, Ethicon, São Paulo, SP, Brazil), in a simple interrupted suture pattern. The patient was radiographed postoperatively. It then received $0.1 \mathrm{mg} / \mathrm{kg}$ of meloxicam, SID, IM, for 5 days (Ouro Fino, Cravinhos, SP, Brazil) and $5 \mathrm{mg} / \mathrm{kg}$ of enrofloxacin, SID, IM, for 5 days (Bayer, São Paulo, SP, Brazil).

The animal recovered uneventfully and started to walk the day after the surgery. It was kept in a restricted space in the wildlife animals' sector for 60 days. It was fed with a liquid to pasty diet initially composed of eggs, lactose-free bovine milk and cream enriched with calcium and multivitamins. Subsequently, minced cooked meat, soy extract, honey, dog food, carrots and beets were added to its pasty diet. Radiographs were taken at 30 and 60 days postoperatively (Figure 1B), under sedation with an association of $5 \mathrm{mg} / \mathrm{kg}$ tiletamine and $5 \mathrm{mg} / \mathrm{kg}$ zolazepam (Virbac, São Paulo, SP, Brazil), IM, showing satisfactory bone union of the fracture. After 90 days, the animal was sent to a rehabilitation program with other anteaters at the zoo.

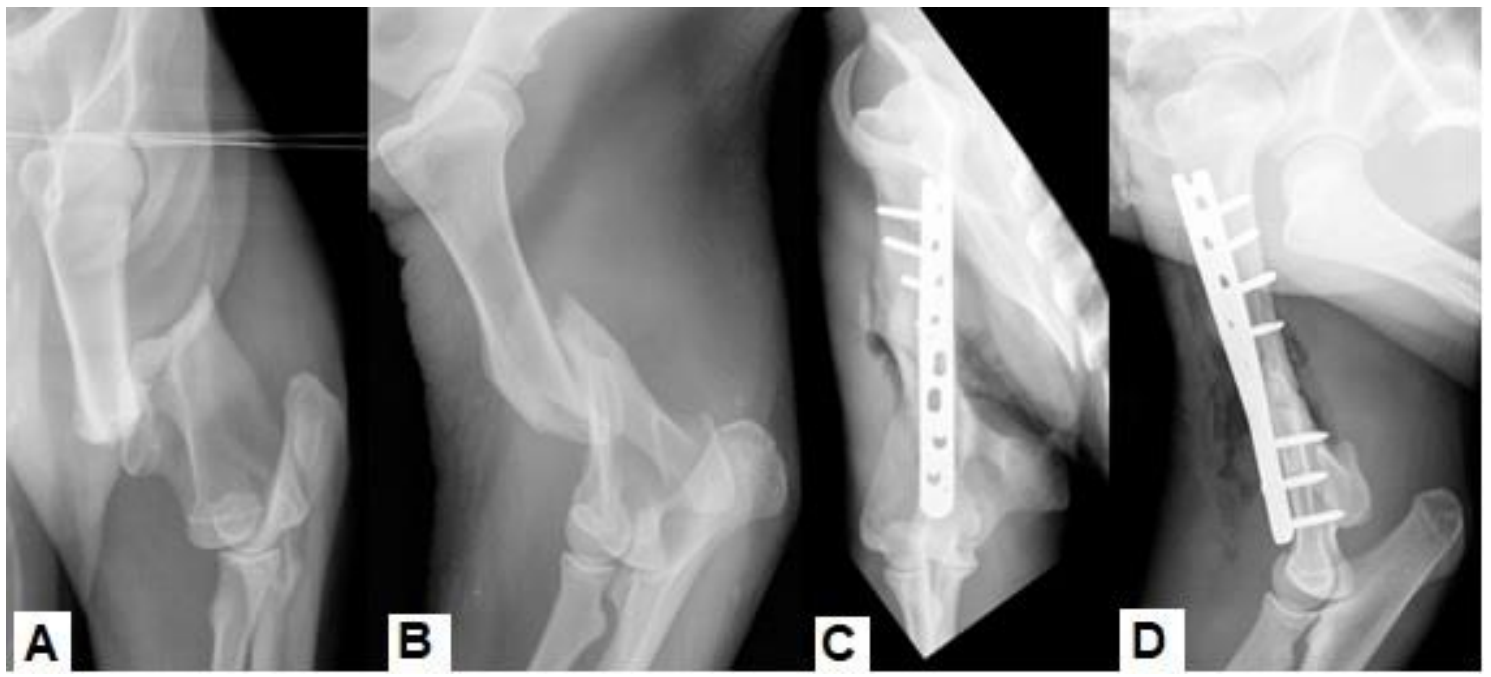

Figure 1. Orthogonal radiographic images showing a short complete oblique fracture in the mid diaphysis of the left humerus from an adult giant anteater (Myrmecophaga tridactyla) (A) e (B), and 60 days after the left humeral osteosynthesis, using a broad $3.5 \mathrm{~mm}$ LCP plate (C) e (D).

\section{DISCUSSION}

Fixation of fractures in wild animals must achieve high-quality and potentially rapid results with minimal postoperative complications, ensuring the survival of the species (Lin et al., 2005; Zimmerman et al., 2010). Overriding potential anatomical, physiological and behavioral challenges of each species is necessary for achieving those goals. The present report describes the successful treatment of a humeral fracture in an adult giant anteater, which involves the need for rigid and long-lasting fixation, considering body weight, anatomical peculiarities of soft and bone tissues and impossibility of postoperative resting. The technique provided early use of the limb and return to locomotion after 24 hours postoperatively, allowing early return to regular activities and collaborating greatly with the individual's survival and referral to subsequent stages of re-adaptation. 


\section{Minto et al.}

Conceptually, fractures in wild animals might be fixed with conventional techniques described, and used in humans and domestic animals, however, the core of the decision-making is how robust it should go for. Even small wild mammals need special attention, especially considering their behavior and daily basis life (ie primates, small wild dogs and cats) (Au et al., 2018; Souza et al., 2020). Medium and large mammals need much more care for deciding the proper method of fixation. It was decided, in the present case, to use a customized broad $3.5 \mathrm{~mm}$ locking plate, which has a reinforced system in thickness of the plate, in spite of using $3.5 \mathrm{~mm}$ external diameter screws. Thus, it provides a rigid (robust) construction sufficient for the current need, given the result obtained. There was rapid functional recovery of the limb and clinical consolidation 60 days after the surgery. Hypothetically, a $20 \mathrm{~kg}$ domestic dog would never need this fixation system; a humeral fracture can be adequately fixed using less robust methods (Sesoko, 2012).

The locking plate promotes superior stability when compared to other methods available for fractures of the humerus. In this case, particularly, it allowed a favorable mechanical environment for bone healing (Matres-Lorenzo et al., 2016; Kenzig et al., 2017). This guideline is applied successfully for humeral fractures of humans and small domestic animals in a regular basis (Walker et al., 2011; Li et al., 2017; Maritato \& Rovesti, 2019). Among several advantages of locking plates, a reduced risk of premature loss of the screw and bone interface and early loosening of the implant can be highlighted (VandeWall et al, 2019).

Other cases of surgical stabilization in animals with robust body mass, restless behavior and the impossibility of postoperative resting have been reported and reinforce the importance of stronger methods of fixation. Ferrigno et al. (2003) performed a fixation of a humeral fracture in a giant anteater using a human LC-DCP plate, and reported difficulties in approaching the fracture site due to the highly developed musculature and unfamiliar anatomy; bone healing was attempt but the implant showed some plastic deformation. A locking plate has been used successfully in fractures of a polar bear (Zimmerman et al., 2010), panthers (Au et al., 2018) and chimpanzees (Pizzi et al., 2020). The double-plating technique was reported to stabilize polar bears by Lin et al.
(2005), showing that this association can represent a good alternative for large patients. In the present case, it was chosen to use only one plate due to the need for excessive dissection of the humeral muscle envelope, the possibility of injury to important anatomical structures and biological disadvantages for the fracture environment. Furthermore, the reinforced plate was considered strong enough, providing rigidity and adequate micromovement control, with no signs of stress protection.

Humeral fractures in human and canine patients are still addressed with interlocking nails, especially when rigid, robust and long-lasting fixation is required (Rajagopal et al., 2017; Fauron et al., 2018). Preliminary anatomical study of an anteater humerus carried out by the authors of this paper revealed a too narrow anteater's medullary canal, not large enough for the desired fixation. The giant anteater has important anatomical particularities, mainly a large and robust muscular envelope around the humerus (Ferrigno et al., 2003; Bonnon et al., 2015). Descriptions of safe corridors for surgical approaches and studies of the musculoskeletal system of this species are limited. Using inappropriate techniques or being unaware of anatomical variations can lead to injuries of noble anatomical structures during surgical approach and cause myopathies, failure of the implants and other complications, putting the animal's survival at risk (Sesoko, 2012; Bonnon et al., 2015). No complications were observed in this report, bringing evidence that humeral fractures in giant anteaters can be successfully repaired if anatomical particularities have been considered.

A craniomedial approach to the humeral diaphysis, with the thoracic limb extended caudally, was performed; an incision of the pectoral muscle to accommodate the plate was required, as reported by Sesoko (2012). This approach was effective in exposing the humeral diaphysis and allowed proper positioning of the implants. The same approach, with some modifications, have been widely used in dogs and cats (Johnson \& Hulse, 2005). Bone union was observed after 60 days, without any complication and with an excellent functional result. Little bone callus formation was demonstrated, evidencing that the stabilization promoted adequate control of the micromovement. The concepts of fracture management and the guidelines for decision 
making described here are applicable or transposable to other species of wild animals, whether free-living, kept in captivity or even domesticated. In view of the lack of reports of stabilization and guidelines for approaching bones in this species, the present report shows that craniomedial approach to the humerus and use of robust fixation with implants for small animals were effective and allowed early functional recovery.

\section{CONCLUSION}

Giant anteater fractures can be successfully treated using implants for small animals; however, it is necessary to have a robust construction that supports the animal's weight and allows expression of its natural behavior without compromising its survival.

\section{REFERENCES}

ALVES, E.G.L.; OLIVEIRA， G.C.A.; MAGALHÃES, T.V. et al. Osteossíntese femoral associada ao biovidro $60 \mathrm{~S}$ em tamanduá-bandeira: relato de caso. Arq. Bras. Med. Vet. Zootec., v.72, p.737-743, 2020.

AU, J.Y.; LEWIS, D.D.; CITINO, S.B. et al. Surgical management of appendicular long-bone fractures in free-ranging florida panthers (puma concolor coryi): six cases (2000-2014). J. Zoo Wildlife Med., v.49, p.162-171, 2018.

BONNON, M.; SOUZA, L.O.; ORTUNHO, V.V. Fixação com pino intramedular em fratura do fêmur em tamanduá-bandeira, Myrmecophaga tridactyla- Linnaeus, 1758. Relato de caso. Rev. Bras. Hig. Sanidade Anim., v.9, p.535-542, 2015.

FAURON, A.H.; DÉJARDIN, L.M.; PHILLIPS, R. et al. Clinical Application of the I-Loc AngleStable Interlocking Nail In 100 traumatic fractures of the humerus, femur and tibia. Vet. Comp. Orthop. Traumatol., v.31, A3642, 2018.

FERRIGNO, C.R.A.; FUTEMA, F.; FEDULLO, D.L. et al. Treatment of radius, ulna and humerus fractures with the aid of a bone morphogenetic protein in a giant anteater (Myrmecophaga tridactyla). Vet. Comp. Orthop. Traumatol., v.16, p.196-199, 2003.
JOHNSON, A.L.; HULSE, D.A. Tratamento de fraturas específicas. In: FOSSUM, T.W. Cirurgia de pequenos animais. 2.ed. São Paulo: Roca, 2005. p.900-1016.

KENZIG, A.R.; BUTLER, J.R.; PRIDDY, L.B. et al. A biomechanical comparison of conventional dynamic compression plates and string-ofpearls ${ }^{\mathrm{TM}}$ locking plates using cantilever bending in a canine Ilial fracture model. BMC Vet. Res., v.13, p.1-6, 2017.

LI, B.B.; LIN, F.; CAI, L.H.; CHEN, Y.; LIN, Z.J. Meta analysis of parallel versus perpendicular double plating for distal humerus fracture of type $\mathrm{C}$ in adults. Zhonghua Wai Ke Za Zhi, v.55, p.626631, 2017.

LIN, R.C.; ENGELI, E.; PROWTEN, A.W. et al. Antebrachial fractures in four captive polar bears (Ursus maritimus). Vet. Surg., v.34, p.358-365, 2005.

MARITATO, K.C.; ROVESTI, G.L. Minimally invasive osteosynthesis techniques for humerus fractures. Vet. Clin. N. Am. Small Anim. Pract., v.50, p.123-134, 2019.

MATRES-LORENZO, L.; DIOP, A.; MAUREL, N. et al. Biomechanical comparison of locking compression plate and limited contact dynamic compression plate combined with an intramedullary rod in a canine femoral FractureGap model. Vet. Surg., v.45, p.319-326, 2016.

MIRANDA, F.; PAULA, C. D. Principais enfermidades em tamanduás cativos. In: MIRANDA, F. Manutenção de tamanduás em cativeiro. 1.ed. São Carlos: Cubo, cap.1, p.240$255,2012$.

PIZZI, R.; ISABEL PIZARRO, A.; MOTA, J. et al. Locking plate femur fracture repair in a juvenile Western chimpanzee (Pan troglodytes verus) in Sierra Leone. J. Med. Primatol., v.00, p.1-4, 2020.

RAJAGOPAL, H.P.; MADAN MOHAN, M.; ANOOP PILAR, K.B.T. Reconstruction of complex distal femur open fracture with distal femoral locking plate and primary autologous free fibular graft. Int. J. Res. Orthop., v.3, p.1066, 2017. 


\section{Minto et al.}

SESOKO, N.F. Estudo anatômico $e$ imaginológico do braço e da coxa em tamanduábandeira (Myrmecophaga tridactyla - Linnaeus, 1758) para determinação de acesso cirúrgico. 2012. 97f. Dissertação (Mestrado em Medicina Veterinária) - Faculdade de Medicina Veterinária e Zootecnia, Universidade Estadual Paulista, Botucatu, SP.

SOUZA SIRAGUSI, R.H.; RAHAL, S.C.; SILVA, J.P. et al. Radiographic evaluation of the forelimbs and hind limbs of marmosets (Callithrix spp.). J. Med. Primatol., v.49, p.71-78, 2020.
VAN DE WALL, B.J.M.; THEUS, C.; LINK, B.C. et al. Absolute or relative stability in plate fixation for simple humeral shaft fractures. Injury, v.50, p.1986-1991, 2019.

WALKER, M.; PALUMBO, B.; BADMAN, B. et al. Humeral shaft fractures: a review. J. Shoulder Elbow Surg., v.20, p.833-844, 2011.

ZIMMERMAN, D.M.; DEW, T.; DOUGLASS, M.; PEREZ, E. Femoral Fracture Repair Using a Locking Plate Technique in an Adult Captive Polar Bear (Ursus maritimus). Vet. Surg., v.39, p.234-238, 2010. 